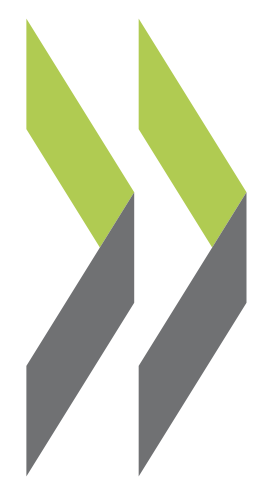

OECD Economics Department Working Papers No. 268

\author{
Inward Investment \\ and Technical Progress \\ in the UK Manufacturing \\ Sector
} Florence Hubert, 


\section{Unclassified}

OECD III OCDE
Organisation de Coopération et de Développement Economiques

Organisation for Economic Co-operation and Development
ECO/WKP(2000)41

OLIS : 12-Oct-2000

Dist. : 20-Oct-2000

ECONOMICS DEPARTMENT

English text only

INWARD INVESTMENT AND TECHNICAL PROGRESS IN THE UK

MANUFACTURING SECTOR

ECONOMICS DEPARTMENT WORKING PAPERS NO. 268

by

Florence Hubert and Nigel Pain

Most Economics Department Working Papers beginning with No. 144 are now available through OECD's Internet Web site at http://ww.oecd.org/eco/eco. 


\begin{abstract}
RÉSUMÉ
This paper investigates the impact of direct investment by foreign-owned companies on technical progress and hence labour productivity in the UK manufacturing sector. Using an industry-level panel data set we find that foreign-owned firms have a significant positive effect on the level of technical efficiency in domestic firms. There is evidence of significant intra-industry and inter-industry spillovers from inward investment. These findings remain robust even when other factors such as imports and domestic R\&D expenditures are allowed for. Inward investment appears to be a much more important source of technical progress than foreign trade.
\end{abstract}

JEL classification: $\mathrm{F} 43, \mathrm{O} 30$

Keywords: Inward investment, multinationals, technical progress, productivity

$* * * * *$

Ce document étudie l'impact de l'investissement direct par des sociétés sous contrôle étranger sur le progrès technique et, par conséquent, la productivité du travail dans le secteur de l'industrie manufacturière du Royaume-Uni. En utilisant un ensemble de données sectorielles en panel, nous trouvons que les sociétés sous contrôle étranger ont un impact positif significatif sur le niveau d'efficacité technique dans les firmes nationales. Il y a des signes de retombées intraindustrielles et interindustrielles significatives consécutives aux investissements entrants. Ces résultats demeurent robustes même en tenant compte d'autres facteurs tels que les importations et les dépenses R-D nationales. Les investissements entrants semblent être une source plus importante de progrès technique que le commerce extérieur.

Classification JEL : F43, O30.

Mots-clés : Investissements étrangers entrants, multinationales, progrès technique, productivité.

Copyright: OECD 2000

Applications for permission to reproduce or translate all, or part of, this material should be made to: Head of Publications Service, OECD, 2 rue André Pascal, 75775 PARIS CEDEX 16, France. 
TABLE OF CONTENTS

INWARD INVESTMENT AND TECHNICAL PROGRESS IN THE
UK MANUFACTURING SECTOR
1. Introduction
2. Methods and data
Data

\section{Figure}

1. Average years of schooling in 1985: B\&L (1996) versus NSD

\section{Tables}

1. Foreign-owned firms in UK manufacturing

2. Characteristics of foreign firms, 1983-92 average

3. Panel data results for industry labour demand 


\title{
INWARD INVESTMENT AND TECHNICAL PROGRESS IN THE UK MANUFACTURING SECTOR
}

\author{
Florence Hubert and Nigel Pain ${ }^{1}$
}

\section{Introduction}

1. The Competitiveness White Paper issued by the UK government in 1998 (DTI, 1998) argues that the creation and exploitation of knowledge are two of the key factors driving the growth process and suggests that foreign direct investment (FDI) is one of the main transmission mechanisms behind the diffusion of knowledge, both codified and tacit, across national borders. Earlier Competitiveness White Papers also suggest that the high level of inward investment into the UK during the 1980s helped to encourage the transfer of innovative production and managerial techniques to UK-owned companies. The desire to attract inward investment is one of the few industrial policies pursued consistently by successive UK governments over the past two decades. The potential importance of multinational companies is emphasised in the literature on endogenous growth (Romer, 1993) and supported by recent empirical evidence that international openness has helped to raise economic growth in the UK (Proudman and Redding, 1998; Barrell and Pain, 1997 and 1999b). The location of economic activity could thus be an important endogenous influence on national growth prospects.

2. The total stock of inward direct investment in the UK rose from 101/4 per cent of GDP in 1978 to 27 per cent of GDP by 1999 (Pain, 2000). There are two periods in which the stock has risen especially rapidly in real terms, the latter half of the 1980s and more recently, since 1997. This is particularly clear from the trends in the flow of new investments summarised in Figure 1. Inflows averaged 21/4 per cent of GDP per annum over 1985-89 and just under 31/2 per cent per annum over 1995-99, compared to a long-run average of 1.6 per cent per annum since 1960. The impact of the growth of inward investment in the 1980s is studied in this paper; the impact of the high level of inward investment in the late 1990s has yet to be examined.

3. The expansion of inward investment over the past two decades has coincided with a pick-up in the growth of labour productivity, particularly in the manufacturing sector, where output per employee hour rose by 4 per cent per annum on average between 1981 and 1996, compared to 2.8 per cent per annum between 1966 and 1981. Our objective in this paper is to assess the arguments put forward in the Competitiveness White Papers by undertaking an econometric study of the effect of inward investment in a

1. Florence Hubert and Nigel Pain are from the National Institute of Economic and Social Research, 2 Dean Trench Street, Smith Square, London SW1P 3HE. They are grateful to Gavin Cameron, Jørgen Elmeskov, Bronwyn Hall, Peter Hart, Peter McGregor, Nick Oulton and other participants at the Econometric Society European Meeting in Santiago de Compostela, the EARIE conference in Torino, the Royal Economic Society conference at St Andrews and the OECD workshop on economic growth for helpful comments and suggestions on this paper. We are grateful to the ESRC for financial support for this research under grant R000237815. 
number of different UK manufacturing industries on technical progress in UK-owned companies, and hence labour productivity and economic growth. The manufacturing sector is chosen because industry level information on inward direct investment can be matched by information on the activities of foreignowned firms from the Annual Census of Production. There are no detailed official data on the activities of foreign-owned firms throughout the UK economy as a whole, although a small number of studies have sought to draw on commercial databases of company accounts.

4. Popular discussion of inward investment and the focus of investment promotion agencies tends to centre around the gross number of jobs believed to be created or safeguarded by such investments. Whilst this can be of obvious importance for particular regions, for the economy as a whole it is arguably not an appropriate way of assessing the benefits of inward investment. Firstly, account needs to be taken of possible displacement effects on domestic employment from the presence of foreign firms (Driffield, 1999). More fundamentally, differences in industrial structure because of inward investment do not provide evidence that the incomes of UK residents have been raised above the levels they would otherwise be at in the absence of any such investments. In an economy such as the UK with flexible real wages, inward investment should affect only the types of jobs available rather than the quantity, unless it can be shown that it has wider effects on the growth process. There would obviously be significant adjustment costs if all foreign firms suddenly left the economy, but ultimately employment could be expected to recover in the economy as a whole provided the real cost of labour fell. A more appropriate question is whether higher foreign investment raises national income. As technical change, rather than the accumulation of inputs into production, is known to be the main driver of economic growth in most of the advanced Western economies over the past fifty years (Crafts and Toniolo, 1996), it is thus natural to focus on whether inward investment affects technical progress.

5. The 1998 Competitiveness White Paper cites evidence from an earlier study by Barrell and Pain (1997). That study found evidence that the stock of inward FDI had a significant positive effect on the rate of technical progress in the manufacturing sector using a time series model of labour demand in the aggregate UK manufacturing sector over 1972-95. In this paper we attempt to assess the robustness of this finding by using a more disaggregated panel data set and including a number of other potential determinants of technical progress.

6. There are a number of important issues that we seek to investigate. First, there is a possibility that the econometric findings for the aggregate manufacturing sector just reflect 'batting average' type effects rather than genuine spillovers from foreign to domestic firms; foreign firms in the UK are more productive on average than domestic ones (Pain, 2000) so a rising share of them within the total population of firms will raise the average level of productivity. Further work is needed to test whether there are also changes in behaviour stemming from these changes in the ownership structure, with spillovers of ideas, technologies and labour from foreign firms to domestic ones. The existence of externalities of this kind would provide one potential justification for the use of fiscal incentives to attract inward investors.

7. Second, the findings for the aggregate manufacturing sector reflect both intra-industry and interindustry effects from inward investment on domestic firms. However in designing investment promotion schemes it is important to know whether the benefits from inward investment are simply felt by firms within the industry in which investment takes place, or whether there are important spillovers to firms in many different sectors.

8. Finally, it is important to establish whether any estimated impact from foreign investment at the industry level is robust to the inclusion of other potential drivers of technical change. Thus we have also sought to test for potential effects from industry-level data on the volume of merchandise imports and the stock of R\&D expenditures on technical progress. Foreign-owned firms now account for a growing proportion of the total R\&D undertaken in the UK (Eltis, 1996; Pain, 2000), so that it may be the case that 
excluding R\&D indicators results in effects being attributed to inward investment in general rather than to inward investors who undertake research. Equally, new technologies developed overseas might be obtained directly through imports of machinery and equipment rather than indirectly from the arrival of foreign firms.

9. To evaluate these questions we test for an impact from the activities of foreign-owned firms on the behaviour of domestically owned firms in a panel data set for a number of two-digit manufacturing industries. The remainder of the paper is as follows. In the next section we outline the basic model used and a number of important econometric issues. The main empirical results are contained in Section 3, looking at the impact of inward investment, imports and R\&D on technical efficiency. Some concluding comments are given in Section 4.

\section{Methods and data}

10. Micro-economic evidence from a number of different countries confirms that there can be important spillover benefits for domestic companies from inward investment (Blomström and Kokko, 1998; Blomström et al., 2000). Such investments provide a channel through which new ideas, technologies and working practices can arrive in host economies. The potential for such externalities provides one reason why governments and regional development agencies frequently seek to offer investment incentives. Spillovers can arise through many routes, including contact with local suppliers, learning by doing and observation, and the movement of knowledge with workers leaving foreign firms for domestic ones. These may take some time to emerge, but all serve to shift the production possibility frontier of the economy outwards.

11. There is some indication from qualitative survey evidence that new technologies and standards have been adopted by UK producers as a result of inward investment. In a study of the impact of technology transfer by US multinational companies Mansfield and Romeo (1980) found that over half of the UK-owned firms in their survey had introduced new products or processes more quickly because of a transfer of a new product or process by a US-based firm to its overseas subsidiary, with around two-thirds of the UK firms indicating that their technological capabilities had been raised by such transfers. More recent evidence suggests that inward investment in the UK has continued to bring about a significant improvement in the product quality of suppliers (Dunning, 1988; PACEC, 1995). The recent expansion of motor vehicle production in Britain following new foreign investments also suggests that there may be important continuing spillovers from foreign investment (Griffith, 1999).

12. Snapshots based on detailed company sector survey data provide a picture of the comparative advantages of foreign firms at particular points in time. A key question left unanswered is whether the build up of foreign investment over time consistently raises the level of labour productivity across the economy as a whole. If foreign firms help to close both idea and object gaps (Romer, 1993), then technical progress is endogenous, providing an explanation and a motive for the efforts made to attract new inward investment.

13. One common way of investigating the impact of absorbed technology on growth is to look at the determinants of total factor productivity (TFP), using an assumed Cobb-Douglas production function:

$$
\mathrm{Q}=\mathrm{A} \mathrm{L}^{\alpha} \mathrm{K}^{\beta} \text { with } \alpha+\beta=1
$$

where $\mathrm{L}, \mathrm{K}$ and A represent labour, fixed capital and an indicator that will pick-up changes in technology and organisational efficiency. Equation [1] can be rearranged to 'back-out' an estimate of TFP levels (or, in first differences, growth): 


$$
\ln (\mathrm{A})=\ln (\mathrm{Y})-\alpha \ln (\mathrm{L})-(1-\alpha) \ln (\mathrm{K})
$$

with $\alpha$ given by the share of labour in national income. Since the weights on capital and labour are imposed to sum to unity, measures of TFP constructed in this fashion will include any scale economies. They may also include the impact of gradual changes in organisational efficiency that raise the level of output produced with given inputs and technologies. Hence TFP may be very different from technical progress. The constructed measure of TFP can be regressed on a number of factors which are thought to determine it. Coe and Helpman (1995) provide a well-known recent example of this approach, with TFP levels related both to the domestic R\&D stock and foreign R\&D stocks embodied in trade.

14. There are a number of difficulties with this method. One general problem is that the CobbDouglas function imposes an elasticity of substitution of unity. If this is invalid, then the constructed measures of TFP will be biased (Nelson, 1966). Rodrik (1997) demonstrates that the biases can be significant when the elasticity of substitution is less than one and technological change has a labour saving bias. Conventional estimates of TFP, derived from [2], then under-estimate the contribution of technical change, with the extent of mis-measurement rising with the degree of labour-saving bias and the growth of the capital-labour ratio, but falling the closer the elasticity of substitution is to unity.

15. Use of a Cobb-Douglas function also forces technical progress to be neutral and excludes the possibility of factor biased technical change. The TFP calculation also makes the assumption that firms are always on their production frontier. In practice firms face adjustment costs, such as hiring and firing impediments and delays in ordering investment goods. In the short-term, demand fluctuations arising from the business cycle can be met by varying utilisation rates and hours worked, implying that factors such as productivity per head may well vary from time to time across industries and countries for reasons that have nothing to do with technological or organisational advances.

16. An alternative approach is to allow for an endogenous elasticity of substitution and endogenous technical progress within estimated dynamic factor demand equations consistent with a particular underlying production structure. In this paper we follow the methodology used by Barrell and Pain (1997 and 1999b) and examine the impact of international linkages on technical change using an estimated labour demand model consistent with an underlying CES production function of the form:

$$
Q=\gamma\left[s(K)^{-\rho}+(1-s)\left(L e^{\lambda t}\right)^{-\rho}\right]^{-(v / \rho)}
$$

Here $\mathrm{v}$ denotes returns to scale, $\gamma$ and $\mathrm{s}$ are production function scale parameters, and the elasticity of substitution $(\sigma)$ is given by $1 /(1+\rho)$. Technical progress is assumed to be labour-augmenting at rate $\lambda_{\mathrm{t}}{ }^{2}{ }^{2} \mathrm{We}$ assume that labour is appropriately measured in terms of employee hours, rather than by just the number of employees.

17. The first-order condition that the marginal product of each input should equal its real price can be used to derive a log-linear 'desired' labour demand equation of the form:

$$
\ln \left(L^{*}\right)=\frac{1+\sigma(v-1)}{v} \ln (Q)-\sigma \ln (w / p)-(1-\sigma) \lambda t+k
$$


where $\mathrm{k}$ denotes a constant. The coefficient on the real producer wage $(\mathrm{w} / \mathrm{p})$ provides a direct point estimate of the elasticity of substitution, allowing the technical progress parameter(s) and returns to scale to be identified. One additional feature of interest apparent from [4] is that a finding of a unit output elasticity could stem from either a unit elasticity of substitution $(\sigma=1)$ or from constant returns to scale $(\mathrm{v}=1)$. Three restrictions are required on [4] to yield a relationship consistent with a Cobb-Douglas production function - a unit elasticity on output and real wages and a zero coefficient on the proxy for technical progress. Imposing these gives a constant long-run factor share $(\mathrm{wL} / \mathrm{pQ}=\mathrm{k})$. These can be tested jointly in any empirical exercise using a factor demand relationship of this kind.

18. Many time series studies of labour demand typically capture technical progress $(\lambda \mathrm{t})$ either by a deterministic time trend or a stochastic one (Barrell et al., 1996; Harvey et al., 1986). The former implies that technical progress is exogenous, rising at a constant rate over time. The latter provides a means of capturing any underlying change in the rate of technical progress, but does not provide an explanation of why it has occurred. However our main interest lies in explicitly testing whether technology transfers and other international spillovers affect the pace of technical change and hence economic growth. We endogenise technical progress by allowing the level within any given industry to be dependent on various factors, including indicators of the scale of the activities of foreign-owned firms (F), imports (M), the R\&D stock $(\mathrm{R})$ as well as an exogenous deterministic time trend $(\mathrm{T})$ :

$$
\lambda \mathrm{t}=\lambda_{\mathrm{T}} \mathrm{T}+\lambda_{\mathrm{F}} \ln (\mathrm{F})+\lambda_{\mathrm{M}} \ln (\mathrm{M})+\lambda_{\mathrm{R}} \ln (\mathrm{R})
$$

This specification implies that technical progress will grow at a constant rate if the key driving factors also grow at a constant rate. The parameters of the technical progress function can be estimated jointly with those of the labour demand schedule by substituting [5] into [4].

19. We allow for adjustment lags arising from factors such as hiring and firing costs by estimating a dynamic model for employment in which the factor demand expression implied by the combination of the marginal productivity condition [4] and the technical progress function [5] is embedded as the long-run steady-state solution. This has the form:

$$
\Delta \ln \left(L_{t}\right)=\beta_{0}+\beta_{1} \Delta \ln \left(Q_{t}\right)+\beta_{2} \ln \left(L_{t-1} / L_{t-1}^{*}\right)+\varepsilon_{t}
$$

Failure to allow for any cyclical effects would imply the strong assumption that companies always use the minimum inputs necessary to produce a given level of output.

20. The model was estimated jointly across a number of industries in a panel model with industryspecific fixed effects. Instrumental variable estimators were used both to allow for the endogeneity of current-dated terms in output and to correct for the bias that might otherwise result from the inclusion of a lagged dependent variable in a fixed effects panel with a comparatively small time dimension. ${ }^{3}$ The diagnostic tests described in Barrell and Pain (1999a) were used to check the reliability of the panel estimates. Returns to scale are freely estimated in all the models reported here.

2. We cannot rule out the possibility that it is in fact neutral unless we estimate jointly a labour and capital demand equation. However this is complicated by the absence of capital stock data at the industry level for foreign and domestic firms.

3. Higher order lags of employment, output, wages and aggregate manufacturing sector capacity utilisation were used as instruments. 


\section{Data}

21. Data at the two-digit level on the value added, employment and labour compensation of domestically-owned firms was obtained from the Annual Census of Production by subtracting data on foreign-owned firms from that for the total population of firms.

22. The long-term trends in the share of foreign-owned firms in the UK manufacturing sector are summarised in Table 1. It can be seen that their share of total output, employment and investment has risen over time. The dominance of US controlled affiliates is clear. They account for over half of the valueadded output produced in foreign-owned firms, even though their relative importance has declined over time as the share of Western European and, to a lesser extent, Japanese firms has risen.

23. Data for foreign-owned firms has been published annually since 1983, but is available only biannually prior to then in official publications. ${ }^{4}$ An additional hurdle is that the Standard Industrial Classification has changed over time. Although we experimented with linking SIC(80) based data for 1983-92 onto SIC(92) data for 1993-96 using an unpublished concordance supplied by the Office for National Statistics, we could not reject the presence of a significant structural break in the link year 1993. Hence the sample used in this paper runs only from 1983-92. We use 15 two-digit industries in all, two of which are formed from the combination of two independent industry groupings. There is total sample size of 135 annual observations.

24. Some summary statistics are reported in Table 2. In each industry it can be seen that the labour productivity of foreign-owned firms has been consistently above that of indigenous firms. The figures also confirm the stylised facts that foreign firms tend to be more capital intensive than domestic firms, with a higher share of non-operatives in their total labour force, and a higher proportion of intermediate inputs. Another potential difference may be scale, with the average size of foreign establishments being larger than domestic ones.

25. All these factors appear to be important, but cannot account fully for the productivity advantages of foreign-owned manufacturing firms. Oulton (2000) reports that greater usage of non-labour inputs can explain some 61 per cent of the higher labour productivity of US-owned establishments in the UK and 97 per cent of that of other foreign-owned ones. Girma et al. (2000) find that after accounting for scale and industrial structure the labour productivity of foreign-owned companies between 1991-96 was 10 per cent higher than UK-owned ones, and the level of total factor productivity was 51/4 per cent higher. Both these differences are statistically significant, and considerably larger for US-owned firms than other foreign firms, especially Japanese ones. Thus it seems clear that there are important firm-specific advantages over and above the scale of operations and the mix of measurable inputs that account for the comparatively higher labour productivity of foreign firms in the UK. These may reflect factors such as better organisational efficiency, greater exposure to international competition and the quality of knowledge-based assets.

26. In the empirical work we measure labour input in terms of employee hours. Time series data on annual hours worked by industry were constructed using information from the New Earnings Survey and the benchmark estimates available in O'Mahony and Wagner (1994). Output prices were measured using two-digit producer price indices. In the absence of any information to the contrary we assumed that prices and hours were similar for domestic and foreign-owned firms in each industry. Data for the volume of imports at 1990 prices were obtained from the Monthly Review of External Trade Statistics and the Annual

4. Data for individual establishments is available on the Annual Business Inquiry database maintained by the ONS at Newport (Griffith, 1999), but we have not sought to construct the missing data in our present research. 
Abstract of Statistics, and converted from a SITC(2) basis into a SIC(80) basis. Annual flow data for R\&D were obtained from the OECD ANBERD database and converted from the ISIC(2) classification into the SIC(80) basis. They were then deflated by the industry output price deflator. Estimates for the stock were generated by using a moving average of past flows over a nine-year period, assuming an annual depreciation rate of 11 per cent as in Carson et al. (1994).

\section{Results}

\subsection{Are there spillovers from foreign firms?}

27. The empirical results are summarised in Table 3. In the first column we report a simple conventional labour demand model which uses only a deterministic time trend as an indicator of technical change. This illustrates that our data set is broadly consistent with the sort of aggregate data set utilised in Barrell and Pain (1997), in that we obtain significant effects from the exogenous trend and the real wage. The elasticity of substitution is estimated to be a little over one-half, and there is some weak evidence of increasing returns to scale. The statistical adequacy of the panel was investigated using a test of first-order serial correlation (as annual data is being used). An auxiliary regression procedure was adopted, with the lagged own-industry residuals being added in as additional regressors. ${ }^{5}$ In all the models reported here the coefficient on the lagged residuals was insignificant, suggesting that there is no evidence of significant serial correlation.

28. In the second column we introduce the lagged total value-added output of foreign-owned firms in the manufacturing sector as a measure of the scale of their operations. This will capture across-industry spillovers as well as intra-industry ones. Similar results were obtained using gross and net foreign output indicators, and so we summarise results using the latter here. The output of foreign-owned firms is found to be significant, and the size and significance of the coefficient on the deterministic time trend drops noticeably. It is also now possible to accept constant returns to scale, although this restriction has not been imposed in the reported regression. The implied technical progress parameter is large, with a 1 per cent rise in the total output of foreign-owned firms estimated to eventually raise technical progress by 1.05 per cent (standard error 0.44$).^{6}$ The exogenous rate of technical change is estimated to be 2.28 per cent per annum (standard error 1 per cent). These results confirm that inward investment has indeed had a positive effect on the performance of domestic firms.

29. To investigate whether the externalities from inward investment are felt within the industry in which investment occurs, or whether they spread into many different sectors we split the foreign-output term into two components using a log transformation. Letting $\Sigma \mathrm{F}_{\mathrm{j}}$ denote the total output of all firms:

$$
\ln \left(\sum F_{j}\right)=\ln \left(F_{i}+\sum_{j \neq i} F_{j}\right)=\ln \left(F_{i}\right)+\ln \left(1+\frac{\sum_{j \neq i} F_{j}}{F_{i}}\right)=\ln \left(F_{i}\right)+\ln \left(F S_{i}\right)
$$

5. The use of lagged residuals implies that either the estimation period should be reduced by one year or that values should be supplied for 1983, since the estimation period begins in 1984. As the former course would result in the loss of 15 observations we use the asymptotically valid procedure of setting the pre-sample residuals to zero, their value under the null of no serial correlation.

6. This can be derived from Table 3 by obtaining the implied long-run parameter on the inward investment term and dividing it through by $(1-\sigma)$. 
The first term captures the within-sector impact of foreign firms, whilst the second allows for spillovers across sectors. The results from re-estimating the models using the two terms instead of the single aggregate foreign output term are shown in the third column of Table 3. Both terms have significant negative coefficients, and although that on the spillover term is marginally larger than that on the intrasector term, the hypothesis of common coefficients cannot be rejected (Wald(1) $=0.07$ ).

30. The robustness of this finding was checked in an alternative model in which foreign output in other sectors was weighted together using information on purchases of intermediate inputs from the 1990 input-output tables. This procedure gives bigger weights to those industries that are important suppliers to each particular industry. The effect was to raise the point estimate of the impact of the inter-industry spillover term on technical progress, but it was still not possible to reject the hypothesis of equal coefficients on the intra-industry and inter-industry terms. The evidence of significant inter-industry spillovers suggests that policies designed to facilitate the dissemination of new business practices across a wide range of industries and improve the overall attractiveness of the UK as a business location for potential investors are likely to be of greater benefit than policies that just offer investment incentives in selected industries.

\subsection{The impact of imports and $R \& D$ on technical progress}

31. There are many other potential sources of technical change apart from inward investment. Two important channels which have been considered in earlier studies (Coe and Helpman, 1995) are domestic R\&D and imports. We begin by discussing the results obtained from adding imports into the model used thus far, before describing the final, preferred specification. Rising import penetration is expected to raise technical progress by allowing greater opportunities for the assimilation of foreign technologies.

32. Technical progress was initially allowed to depend on five different variables, the deterministic trend, the two inward investment terms and two equivalent variables for import volumes. The imposition of a common coefficient on the two inward investment terms could not be rejected by the data [p-value 0.36], but the imposition of common coefficients on the import terms was [p-value 0.011]. There was evidence of a significant positive effect from intra-industry imports, but an insignificant one from the import spillover term. The results from including only the intra-industry term in imports (denoted $\mathrm{M}_{\mathrm{i}}$ ) are reported in the fourth column of Table 3 .

33. These indicate that there are significant effects from both forms of international openness, but that they are much larger from inward investment than from imports. A 1 per cent rise in intra-industry import volumes is estimated to raise the level of technical progress by 0.31 per cent (standard error 0.14 per cent), whereas a 1 per cent rise in intra-industry inward investment raises technical progress by 0.82 per cent (standard error 0.39 per cent). Thus including imports does have an important effect on the other key production function coefficients, but it does not result in the disappearance of the inward investment effects. One implication of the finding that inter-industry effects from inward investment are important, whereas those from imports are not, is that the former may be reflecting the diffusion of new ideas and working practices rather than new technologies.

34. An equivalent general equation was initially specified for the model including the stock of $R \& D$ expenditures (at constant prices). In contrast to the findings for imports, the own industry $\left(\mathrm{R}_{\mathrm{i}}\right)$ and the spillover $\left(\mathrm{RS}_{\mathrm{i}}\right) \mathrm{R} \& \mathrm{D}$ terms were jointly significant (Wald(2)=21.65), although neither were individually significant at conventional levels. This suggests that technical progress in manufacturing industries is partly dependent on R\&D activities, but it is difficult to pin down whether it arises from intra-industry R\&D or whether there are important spillover effects from R\&D in other industries. The estimated effects are large, but with a large standard error, suggesting that there may well be considerable variation across 
sectors. This imprecision may stem from the need to construct proxies for the stock of R\&D. A 1 per cent rise in the intra-industry stock of $\mathrm{R} \& \mathrm{D}$, which is something that may be difficult to achieve, is estimated to raise the level of technical progress by 2.92 per cent (standard error 1.84 per cent).

35. The inclusion of the R\&D terms again acts to reduce the size of the coefficients on the inward investment terms, but both remain significant, and the imposition of a common coefficient on the two inward investment terms can still be accepted (Wald(1)=1.65). The results imply that a 1 per cent rise in the output of foreign firms in a particular industry will raise technical progress by 0.53 per cent (standard error 0.21 per cent) in domestic firms in that industry, while a 1 per cent rise in the spillover term will raise technical progress by 0.65 per cent (standard error 0.26 per cent). It has clearly been important to include the additional terms in imports and $R \& D$ since they have reduced the size of the estimated effect from inward investment by almost a half. However it remains considerably larger than that obtained by Barrell and Pain (1997), suggesting either that the effects have strengthened over time, or that the panel analysis has highlighted factors obscured by a single analysis for the manufacturing sector as a whole. It confirms that policies which help to raise the level of inward investment may have a long-term impact on the size of the UK economy.

36. It is interesting to note how some of the other parameters have also changed as imports and R\&D have been introduced. The deterministic trend has become insignificant, suggesting that the R\&D and imports variables effectively capture the effects previously modelled as exogenous. The point estimate of returns to scale has declined consistently, and by the fifth column there is only marginal evidence of increasing returns.

37. Our results also have wider modelling implications. Studies of the determinants of either total factor productivity or labour productivity often assume that the production process is Cobb-Douglas (for example, Coe and Helpman, 1995). In our framework it is possible to test the joint restrictions that must hold if the production process can be described by a Cobb-Douglas function. These set of restrictions were consistently rejected by the data, implying that use of a Cobb-Douglas function may be unduly restrictive and generate biased estimates of TFP. ${ }^{7}$

\section{Concluding comments}

38. For many years successive UK governments have emphasised the potential beneficial effects of inward investment on the UK economy. However, to date, there has been relatively little quantitative econometric evidence as to the extent to which such investment has affected the growth process. Our general findings indicate that the benefits of inward investment have indeed been felt in the manufacturing sector. These findings appear to be robust to the presence of other potential determinants of growth such as imports and domestic R\&D expenditures. They do not indicate that inward investment is the only source of technical change in the UK economy, but they do indicate that it is an important and significant one, and one which should play an important part in the explanation of the improved productivity seen in the manufacturing sector in the last two decades.

39. The evidence points to significant externalities from the scale of operations of foreign firms on the behaviour of domestic firms. We obtain significant within-industry effects and evidence of significant spillovers from foreign firms located elsewhere in the manufacturing sector. The finding of significant across-industry spillovers suggests that at least some inward investors help to bring ideas that can be

7. For example in column 2 of Table 3 four restrictions are required - long-run unit output and wage elasticities and zero coefficients on the time trend and foreign firms variable. These are jointly rejected by the data $[$ Wald $(4)=42.28]$. 
applied across a wide range of industries. The challenge for future research is to seek to pin down the factors that govern the size, speed and distribution of spillovers from inward investors and to investigate further whether they are generic or confined to investors of particular nationality or investors in specific industries. 
Figure 1. UK FDI inflows as a per cent of GDP (annual averages)

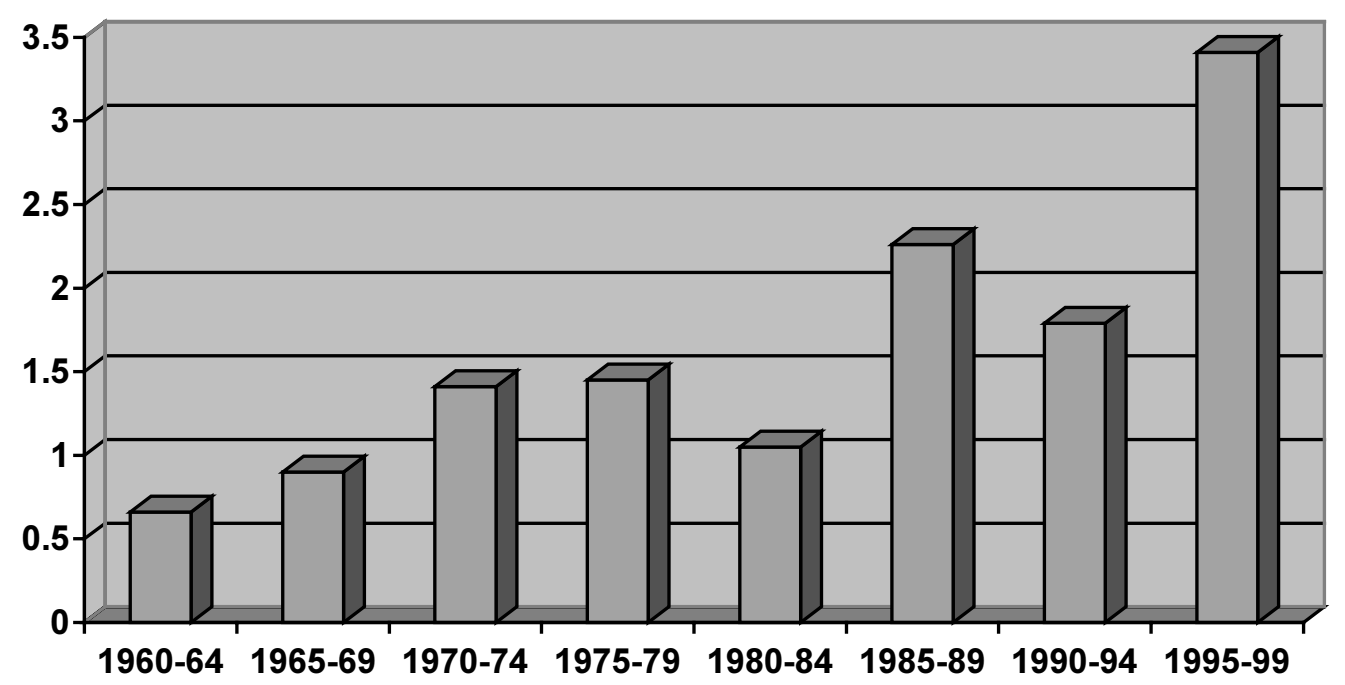

Source: Pain (2000, Chart 1.2)

Table 1. Foreign-owned firms in UK manufacturing (annual averages)

\begin{tabular}{lccc}
\hline & $\mathbf{1 9 7 3 - 7 9}$ & $\mathbf{1 9 8 1 - 8 9}$ & $\mathbf{1 9 9 0 - 9 7}$ \\
\cline { 2 - 4 } Share of foreign-owned firms (\%) & 17.4 & 18.5 & 23.9 \\
Gross value added & 18.1 & 22.2 & 30.9 \\
Net capital expenditure & 12.8 & 13.8 & 17.4 \\
Total employment & 12.0 & 12.8 & 16.0 \\
Employment of operatives & 15.2 & 16.4 & 19.9 \\
Employment of non-operatives & & & \\
& & & \\
Nationality of investor (\%) & 72.9 & 65.2 & 53.1 \\
United States & 18.7 & 20.3 & 29.8 \\
Western Europe & 0.1 & 1.0 & 6.6 \\
Japan & 8.3 & 13.5 & 10.5 \\
Rest & & & \\
\hline
\end{tabular}

Source: Annual Census of Production, various issues.

Note: Nationality shares based on share of gross value added. Employment data by occupation not available for 1997. 
Table 2. Characteristics of foreign firms, $1983-92$ average (domestic firms $=100$ )

\begin{tabular}{|c|c|c|c|c|c|}
\hline Industry & $\mathrm{SIC}(80)$ & $\begin{array}{l}\text { Labour } \\
\text { productivity }\end{array}$ & $\begin{array}{c}\text { Share of non- } \\
\text { operatives }\end{array}$ & $\begin{array}{l}\text { Investment- } \\
\text { output ratio }\end{array}$ & $\begin{array}{l}\text { Gross-net output } \\
\text { ratio }\end{array}$ \\
\hline Basic metals industries & 22 & 111.1 & 102.6 & 99.8 & 122.1 \\
\hline $\begin{array}{l}\text { Chemicals and man-made } \\
\text { fibres }\end{array}$ & $25+26$ & 110.8 & 114.1 & 103.7 & 102.5 \\
\hline Metal manufacturing & 31 & 140.0 & 122.4 & 132.2 & 116.6 \\
\hline Mechanical engineering & 32 & 128.1 & 119.3 & 112.1 & 113.7 \\
\hline $\begin{array}{l}\text { Electrical engineering } \\
\text { and office machinery }\end{array}$ & $33+34$ & 133.8 & 105.3 & 153.0 & 135.2 \\
\hline Food, drink and tobacco & $41+42$ & 173.0 & 127.9 & 96.6 & 98.1 \\
\hline Textiles & 43 & 128.4 & 136.0 & 149.7 & 110.9 \\
\hline Footwear and clothing & 44 & 150.3 & 131.8 & 81.5 & 103.3 \\
\hline Timber and wooden furniture & 46 & 142.6 & 139.8 & 297.0 & 107.1 \\
\hline Paper and publishing & 47 & 132.6 & 102.2 & 124.0 & 108.2 \\
\hline Plastics and rubber & 48 & 133.0 & 117.1 & 80.5 & 96.8 \\
\hline
\end{tabular}

Source: calculations from Census of Production. 


\section{Table 3. Panel data results for industry labour demand}

Dependent variable: $\Delta \ln \left(\mathrm{L}_{\mathrm{it}}\right)$; sample period 1984-92

\begin{tabular}{|c|c|c|c|c|c|}
\hline & [1] & [2] & [3] & [4] & [5] \\
\hline$\Delta \ln \left(\mathrm{Q}_{\mathrm{it}}\right)$ & $0.2650(3.6)$ & $0.2490(3.1)$ & $0.2426(2.9)$ & $0.2880(3.9)$ & $0.3753(5.7)$ \\
\hline $\operatorname{Ln}\left(\mathrm{L}_{\mathrm{i}, \mathrm{t}-1}\right)$ & $-0.3202(4.9)$ & $-0.2541(4.4)$ & $-0.2519(4.4)$ & $-0.2664(4.5)$ & $-0.3060(5.7)$ \\
\hline $\operatorname{Ln}\left(Q_{i, t-1}\right)$ & $0.2450(4.8)$ & $0.2245(4.6)$ & $0.2234(4.8)$ & $0.2573(5.5)$ & $0.3039(6.6)$ \\
\hline $\operatorname{Ln}\left(\mathrm{W}_{\mathrm{i}, \mathrm{t}-1} / \mathrm{P}_{\mathrm{i}, \mathrm{t}-1}\right)$ & $-0.1709(2.3)$ & $-0.1196(4.6)$ & $-0.1188(4.7)$ & $-0.1309(5.2)$ & $-0.1525(6.4)$ \\
\hline TIME & $-0.0088(3.4)$ & $-0.0031(1.9)$ & $-0.0030(1.9)$ & $-0.0017(1.1)$ & $0.0076(1.3)$ \\
\hline $\operatorname{Ln}\left(F_{t-1}\right)$ & & $-0.1413(3.2)$ & & & \\
\hline $\operatorname{Ln}\left(F_{i, t-1}\right)$ & & & $-0.1450(3.2)$ & $-0.1107(2.7)$ & $-0.0807(2.2)$ \\
\hline $\operatorname{Ln}\left(\mathrm{FS}_{\mathrm{i}, \mathrm{t}-1}\right)$ & & & $-0.1483(3.3)$ & $-0.1212(3.1)$ & $-0.0993(3.7)$ \\
\hline $\operatorname{Ln}\left(M_{\mathrm{I}, \mathrm{t}-1}\right)$ & & & & $-0.0424(2.3)$ & $-0.0493(2.6)$ \\
\hline $\operatorname{Ln}\left(\mathrm{R}_{\mathrm{i}, \mathrm{t}-1}\right)$ & & & & & $-0.4494(1.6)$ \\
\hline $\operatorname{Ln}\left(\mathrm{RS}_{\mathrm{i}, \mathrm{t}-1}\right)$ & & & & & $-0.4910(1.8)$ \\
\hline$\overline{\mathrm{R}}^{2}$ & 0.692 & 0.730 & 0.727 & 0.743 & 0.761 \\
\hline Standard error & $2.62 \%$ & $2.43 \%$ & $2.45 \%$ & $2.37 \%$ & $2.29 \%$ \\
\hline Serial correlation & $\operatorname{Chi}(1)=1.61$ & $\operatorname{Chi}(1)=0.04$ & $\operatorname{Chi}(1)=0.06$ & $\operatorname{Chi}(1)=0.13$ & $\operatorname{Chi}(1)=0.90$ \\
\hline Returns to scale (v) & $2.019(0.312)$ & $1.281(0.276)$ & $1.272(0.276)$ & $1.071(0.219)$ & $1.016(0.243)$ \\
\hline Elasticity of substitution $(\sigma)$ & $0.534(0.021)$ & $0.471(0.023)$ & $0.472(0.024)$ & $0.492(0.025)$ & $0.498(0.026)$ \\
\hline
\end{tabular}

Note: heteroscedastic-consistent t-statistics in parentheses, apart for returns to scale and the elasticity of substitution which are long-run standard errors. 


\section{BIBLIOGRAPHY}

BARRELL, R. and N. PAIN (1997), "Foreign direct investment, technological change and economic growth within Europe", The Economic Journal, Vol. 107, pp. 1770-1786.

BARRELL, R. and N. PAIN (1999a), "Trade restraints and Japanese direct investment flows", European Economic Review, Vol. 43, pp. 29-45.

BARRELL, R. and N. PAIN (1999b), "Domestic institutions, agglomerations and foreign direct investment in Europe", European Economic Review, Vol. 43, pp. 925-934.

BARRELL, R., N. PAIN. and G. YOUNG (1996), "The cross-country demand for labour in Europe", Weltwirtschaftliches Archiv, Vol. 132, pp. 638-650.

BLOMSTRÖM, M. and A. KOKKO (1998), "Multinational corporations and spillovers", Journal of Economic Surveys, Vol. 12, pp. 247-278.

BLOMSTRÖM, M., A. KOKKO and S. GLOBERMAN (2000), “The determinants of host country spillovers from foreign direct investment: a review and synthesis of the literature", in Pain (2000).

CARSON, C.S., B.T. GRIMM and C.E. MOYLAN (1994), "A satellite account for research and development”, Survey of Current Business, Vol. 74/11, pp. 37-71.

COE, D. and E. HELPMAN (1995), "International R\&D spillovers", European Economic Review, Vol. 39, pp. 859-887.

CRAFTS, N. and G. TONIOLO (1996), Economic Growth In Europe Since 1945, Cambridge University Press.

DRIFFIELD, N. (1999), "Indirect employment effects of foreign direct investment into the UK", Bulletin of Economic Research, Vol. 51, pp. 207-221.

DTI (1998), Our Competitive Future: Building The Knowledge Driven Economy, The Competitiveness White Paper: Analysis and Background, Department of Trade and Industry, London.

DUNNING, J.H. (1988), “US and Japanese manufacturing affiliates in the UK: comparisons and contrasts", in Dunning, J.H., Explaining International Production, Harper-Collins.

ELTIS, W. (1996), "How low profitability and weak innovativeness undermines UK industrial growth", Economic Journal, Vol. 106, pp. 184-195.

GIRMA, S., D. GREENAWAY, K. WAKELIN and N. SOUSA (2000), "Host country effects of FDI in the UK: recent evidence from firm level data", in Pain (2000). 
GRIFFITH, R. (1999), "Using the ARD establishment level data to look at foreign ownership and productivity in the United Kingdom", The Economic Journal, Vol. 109, pp. F416-F442.

HARVEY, A.C., S.G.B HENRY, S. PETERS and S. WREN-LEWIS (1986), "Stochastic trends in dynamic regression models: an application to the employment-output equation", The Economic Journal, Vol. 96, pp. 975-985.

MANSFIELD, E. and A. ROMEO (1980), "Technology transfer to overseas subsidiaries by US based firms", Quarterly Journal of Economics, vol. 95, pp. 37-750.

NELSON, R.R. (1966), "The CES production function and economic growth projections", Review of Economics and Statistics, Vol. XLVIII, pp. 326-328.

O'MAHONY, M. and K. WAGNER (1994), "Changing fortunes: an industry study of British and German productivity growth over three decades", NIESR Report Series No. 7.

OULTON, N. (2000), "Why do foreign-owned firms in the UK have higher labour productivity?", in Pain (2000).

PACEC (1995). Assessment of the Wider Effects of Foreign Direct Investment in Manufacturing in the UK. Report by PA Cambridge Economic Consultants for Department of Trade and Industry.

PAIN, N. (2000) (ed.), Inward Investment, Technological Change And Growth: The Impact Of Multinational Corporations On The UK Economy, Macmillan Press, forthcoming.

PROUDMAN. J. and S. REDDING (eds.) (1998), Openness And Growth, Bank of England.

RODRIK, D. (1997), "TFPG controversies, institutions and economic performance in East Asia”, NBER Working Paper No. 5914.

ROMER, P. (1993), "Idea gaps and object gaps in economic development", Journal of Monetary Economics, Vol. 32, pp. 543-573. 


\section{ECONOMICS DEPARTMENT}

\section{WORKING PAPERS}

267. Aggregate Growth: What have we Learned from Microeconomic Evidence? (October 2000) John Haltiwanger

266. Determinants of Long-term Growth: A Bayesian Averaging of Classical Estimates (BACE) Approach (October 2000) Gernot Doppelhofer, Ronald I. Miller and Xavier Sala-i-Martin

265. The Great Reversals: The Politics of Financial Development in the $20^{\text {th }}$ Century (October 2000) Raghuram G. Rajan and Luigi Zingales

264. Trade and Growth: Still Disagreement about the Relationship (October 2000) Robert Baldwin

263. Growth Effects of Education and Social Capital in the OECD Countries (October) Jonathan Temple

262. Human Capital in Growth Regressions: How Much Difference Does Data Quality Make? (October 2000) Angel de la Fuente and Rafael Doménech

261. Raising the Speed Limit: US Economic Growth in the Information Age (October 2000) Dale W. Jorgenson and Kevin J. Stiroh

260. Summary of an Informal Workshop on the Causes of Economic Growth (October 2000) Jonathan Temple

259. Knowledge, Technology and Economic Growth: Recent Evidence from OECD Countries (October 2000) Andrea Bassanini, Stefano Scarpetta and Ignazio Visco

258. Average Effective Tax Rates on Capital, Labour and Consumption (October 2000) David Carey and Harry Tchilinguirian

257. The Health Care System in Poland (September 2000) Nathalie Girouard and Yutaka Imai

256. Public Expenditure Reform: The Health Care Sector in the United Kingdom (August 2000) Vincent Koen

255. Regulatory Reform in Road Freight and Retail Distribution (August 2000) Olivier Boylaud

254. Regulation, Market Structure and Performance in Air Passenger Transportation (August 2000) Rauf Gonenc and Giuseppe Nicoletti

253. Policy Interdependence during Economic Transition: the Case of Slovakia 1999-2000 (June 2000) Joaquim Oliveira Martins and Tristan Price

252. E-Commerce: Impacts and Policy Challenges (June 2000) Jonathan Coppel 


\section{$\mathrm{ECO} / \mathrm{WKP}(2000) 41$}

251. The Implementation and the Effects of Regulatory Reform: Past Experience and Current Issues (June 2000) Rauf Gonenc, Maria Maher and Giuseppe Nicoletti

250. The Concept, Policy Use and Measurement of Structural Unemployment: Estimating a Time Varying NAIRU across 21 OECD Countries

(June 2000) Pete Richardson, Laurence Boone, Claude Giorno, Mara Meacci, David Rae and David Turner

249. Options for Reforming the Spanish Tax System

(June 2000) Isabelle Joumard and Aristomène Varoudakis

248. Economic Growth in the OECD Area: Recent Trends at the Aggregate and Sectoral Level (June 2000) Stefano Scarpetta, Andrea Bassanini, Dirk Pilat and Paul Schreyer

247. Economic Effects on the 1999 Turkish Earthquakes: an Interim Report (June 2000) Alexandra Bibbee, Rauf Gonenc, Scott Jacobs, Josef Konvitz and Robert Price

246. Policy Influences on Economic Growth in OECD Countries: an Evaluation of the Evidence (June 2000) Sanghoon Ahn and Philip Hemmings

245. The Tax System in the Czech Republic (May 2000) Chiara Bronchi and Andrew Burns

244. The Tax System in Norway: Past Reforms and Future Challenges (May 2000) Paul van den Noord

243. A Changing Financial Environment and the Implications for Monetary Policy (May 2000) Paul Mylonas, Sebastian Schich, Gert Wehinger

242. Carbon Emission Leakages: a General Equilibrium View (May 2000) Jean-Marc Burniaux and Joaquim Oliveira Martins

241. The Healthcare System in Hungary (April 2000) Eva Orosz and Andrew Burns

240. Comparing Semi-Structural Methods to Estimate Unobserved Variables: the HPMV and Kalman Filters Approaches

(April 2000) Laurence Boone

239. New Issues in Public Debt Management: Government Surpluses in Several OECD Countries, the Common Currency in Europe and Rapidly Rising Debt in Japan (April 2000) Paul Mylonas, Sebastian Schich, Thorsteinn Thorgeirsson and Gert Wehinger

238. Regulation, Industry Structure and Performance in the Electricity Supply Industry (April 2000) Faye Steiner

237. Regulation, Market Structure and Performance in Telecommunications (April 2000) Olivier Boylaud and Giuseppe Nicoletti

236. Predicting the Evolution and Effects of the Asia Crisis from the OECD Perspective (April 2000) Pete Richardson, Ignazio Visco and Claude Giorno

235. Modelling Manufacturing Export Volumes Equations A System Estimation Approach (April 2000) Keiko Murata, David Turner, David Rae and Laurence Le Fouler 